\title{
Study on Soil Heat Imbalance of Ground Source Heat Pump based on Complex Network System
}

\author{
He Ren \\ School of Civil and Environmental Engineering, University of Science \& Technology Beijing, Beijing, \\ China
}

Keywords: Complex Network System, Ground-Coupled Heat Pump System, Soil Thermal Balance, Operation Strategy.

\begin{abstract}
The simulation model of ground-coupled heat pump system supplemented by the cooling tower is established in this paper aiming at the thermal balance problems existing in the ground-coupled heat pump system. The operation strategy and the design scheme of compound system are analyzed. He result indicates that: if the buried pipe length of the existing ground-coupled heat pump system is designed in accordance with the maximum heat release quantity in summer, the capacity of cooling tower can be selected in terms of the thermal balance requirement; the buried pipe of the new-type compound system can be designed in accordance with the thermal load of winter, it shall be appropriate to select the cooling tower scheme based on the difference between cooling and heating load, and the supplementary cooling tower scheme shall be optimally launched when the temperature of ground-coupled heat pump entrance exceeds $26^{\circ} \mathrm{C}$; additionally, the ground-coupled heat pump is adopted to assume all heating load in the winter and partial cooling load in summer. Furthermore, the better operation effect can be acquired through adopting the supplementary scheme combing the cooling water unit and the cooling tower for summer. Given the mentioned information, it can be acquired that this paper is attached great reference value for the design and operation of compound ground-coupled heat pump.
\end{abstract}

\section{Introduction}

The year-by-year rising and declining soil temperature triggered by the load difference in winter and summer of constructions existing in the long-term operation of single ground-coupled heat pump system has already been perceived as the bottleneck restricting the large-scale and wide application of such system. It is acquired through summarizing the existing research literature of thermal balance that, for the small-scale project of villa, when over 10 tube wells are arranged, and the accumulated load ratio between winter and summer is less than 3 , the thermal imbalance of the long-term operation of ground-coupled heat pump system can be approximately ignored; additionally, when the tube wells are increased, or the accumulated load ratio between winter and summer is increased, the buried pipe spacing can be preliminarily increased or the buried pipe capacity can be largely designed as to elevate the soil temperature to the acceptable scope; eventually the problem remains unsolved through adopting the mentioned approaches, the supplementary cooling or heating plant can be adopted to constitute the compound ground-coupled heat pump system. Hence, it shall be deemed as the normal option to jointly assume the cooling and heating load of the construction.

\section{Simulation Model of Compound Ground-coupled Heat Pump System}

\section{Introduction of construction model}

The construction model in this paper is based on a certain ground-coupled heat pump experiment project of Shanghai. The cooling load of air conditioner is designed as $300 \mathrm{~kW}$, and the heating load 
is designed as $117 \mathrm{~kW}$. When selecting the scale of construction, the currently normal buried pipe size of ground-coupled heat pump system is considered. The design of the buried pipe shall be detailed in the following paragraphs.

In terms of the characteristics of Shanghai construction load, the compound ground-coupled heat pump system with the supplementing cold source of cooling tower is adopted. The water way of the cooling tower is connected to the water way of outdoor buried pipe in series. And yet the plate heat exchanger is adopted to separate two water ways as to prevent the buried pipe from being blocked due to the water quality of the cooling tower water way. The air conditioning system with the VAV of primary return air is adopted is the airside. The operating characteristics and strategy of outdoor water loop composed by the buried pipe and the cooling tower are analyzed. For this reason, the form of terminal system is not detailed hereof in this paper. The water loop of this system draws on four three-way valves to switch the operating condition in summer and winter. In summer, the cooling water system operation can be split into three types: firstly the single cooling tower operation which is the conventional air conditioning system allowing cooling tower to release the heat of condensation; secondly the single buried pipe which is the conventional ground-coupled heat pump system; thirdly the operation connecting the two mentioned types via the plate heat exchanger, which is the compound ground-coupled heat pump system. This paper shall meet the construction load requirement, guarantee the high-efficiency of unit and alleviate the thermal imbalance of soil through switching three types of operation.

\section{Design of buried pipe}

The thermal conductivity of the soil and the initial ground temperature are deemed as the vital parameters to design the buried-pipe underground heat exchanger. The former one is normally acquired through the thermal response test in the field or through indoor test. The soil thermal conductivity coefficients of all stratums are shown in Figure1. The latter is normally acquired through the monitoring well. In accordance with the result of experiment and test, the initial ground temperature on the average of soil within $100 \mathrm{~m}$ of Shanghai region reaches between $18.6 \sim 19.7^{\circ} \mathrm{C}$. The soil temperature is varied in accordance with the depth data in this project, which is shown in Figure 2.

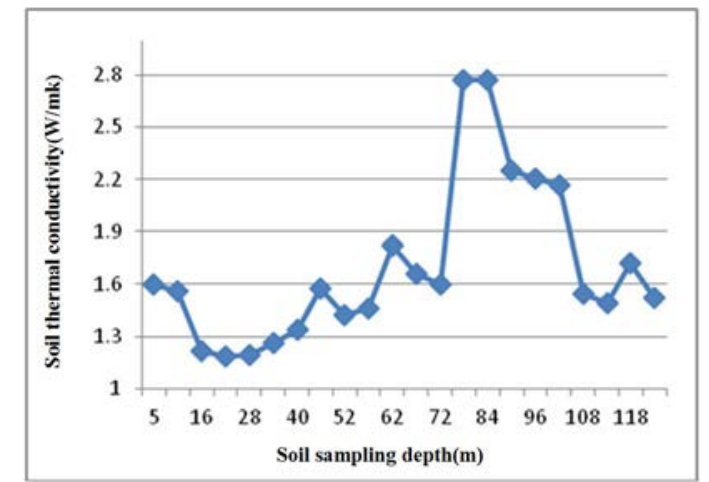

Fig.1. Heat conductivity coefficient of all stratums

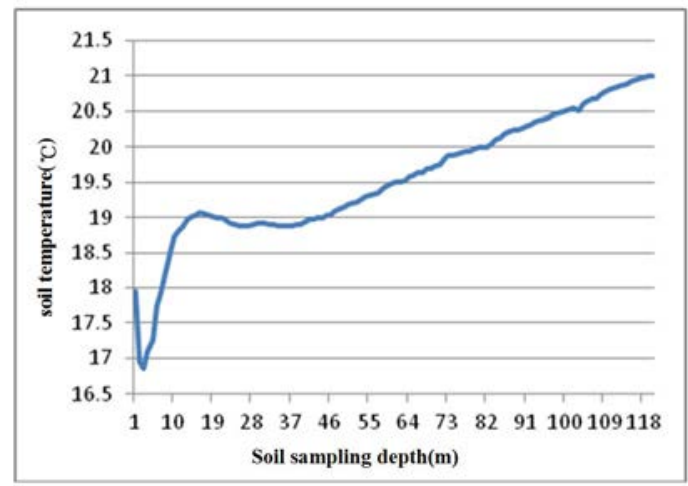

Fig.2. Curve of soil temperature variation in accordance with depth

The depth of vertically buried pipe normally reaches between $52.5 \sim 175.0 \mathrm{~m}$. Under such depth 
of stratum, groundwater shall be inevitably seeped. Under the equal hydraulic gradient, the maximum seepage velocity is in the granule and coarse sand stratums. While the granule in the structural layer is reduced to the silty sand, the seepage velocity can be reduced by 4 magnitudes; for the clay layer, the seepage velocity shall be further decreased by 3 magnitudes. The influence of the seepage on underground heat exchanger is primarily dependent on the seepage velocity. In accordance with the ground physical property result of this project, the geology over $78 \mathrm{~m}$ is mainly composed by the clay, the fine sand is the main constituent of geology in the depth of $78 \sim 90 \mathrm{~m}$, the silt takes up the primary place in the depth of $90 \sim 102 \mathrm{~m}$, and merely the geology in the depth of $102 \sim 108 \mathrm{~m}$. The geology in the depth of $108 \sim 120 \mathrm{~m}$ remains the clay. For this reason, in this project, the soil layer over $83 \mathrm{~m}$ is mainly composed by the clay, creating less seepage velocity. Additionally, less error shall be raised through ignoring the influence of seepage. Accordingly the influence of seepage can be ignored.

In accordance with the test result, the heat exchange amount per well depth in summer is recommended to be $60 \mathrm{~W} / \mathrm{m}$, and heat exchange amount per well depth in winter is recommended to be $40 \mathrm{~W} / \mathrm{m}$. Hence, 80 vertical underground exchanger wells are designed in this project. The drilling depth reaches $83 \mathrm{~m}$, and the drilling spacing reaches $4 \mathrm{~m}$. The scale of 80 exchanger wells as the research basis is able to reflect the heat transfer phenomenon of the buried pipe area during the long-term operation of ground-coupled heat pump system. To further enlarge the scale of pipe, the larger multiple clusters of wells with 80 wells per cluster can be recommended, as to constitute the larger scale of pipe cluster. Each pipe cluster follows the same heat exchange rule, that is to overlap the exchange amount.

\section{Constructing the simulation model of compound ground-coupled heat pump system}

The TRNSYS17 is adopted as to construct the simulation model of ground-coupled heat pump system. The TRNSYS software was initially developed in the Solar Energy Laboratory of Wisconsin Madison. Wider scope is involved, and the operation status of various systems can be dynamically simulated. The most obvious superiority is that the user is allowed to modify or write the new model in accordance with the personal requirement and add it to the program library. It can not only simulate and optimize the air conditioning system, but analyze the energy consumption of construction and research the construction's thermal property. TRNSYS is the modularized dynamic simulation software. The so-called modularization means that, all the systems are composed by several minor systems (module), and each module is to realize a special function.

In this paper, the eQuest is firstly adopted to calculate the yearly and hourly load of the construction, including the derived hourly cooling and heating load of construction, like fresh air and cooling losses. Secondly, the data is introduced to TRNSYS through Type9 Data Reader, which can effectively simplify the TRNSYS model and further reduce the time of simulation computation. 


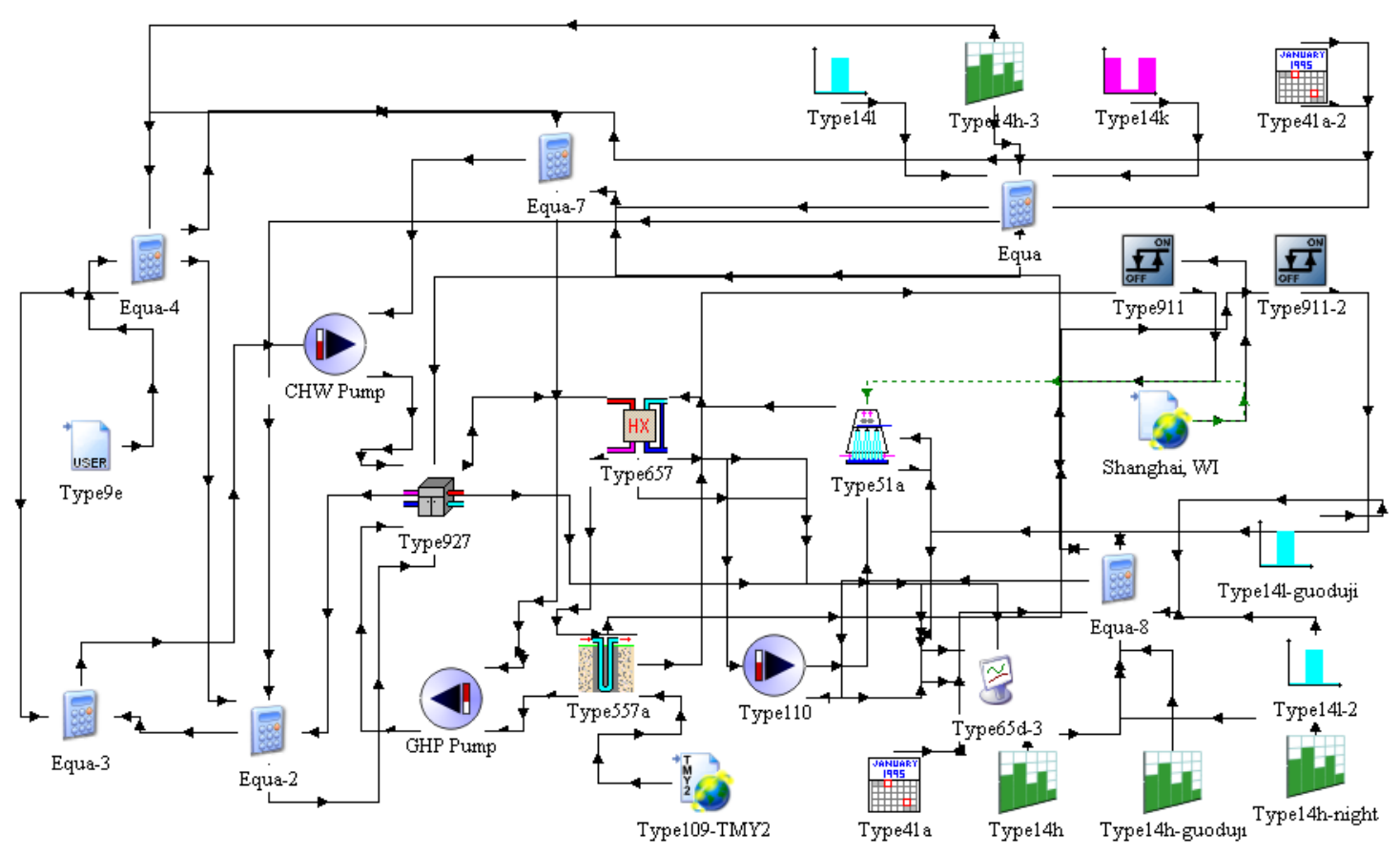

Fig.3. System structure of air conditioning system in Trnsys software

The models used in this figure include Type 9: Data Reader (Generic Data Files); Type557: Vertical Ground Heat Exchanger; Type927: Water to Water Heat Pump; Type51: Cooling Tower; Type657: Heat Exchanger; type110: Variable Speed Pump. The main COP of water-water heap pump unit shall be affected by the flow, outflow temperature on load side and outflow temperature on buried pipe side. The cooling COP variation is displayed in Figure 4. The Load EWT involved refers to the inflow temperature of unit on chilled water side, the Source EWT refers to the inflow temperature on the chilled water side, and frequency of water pump in the system can all be converted.

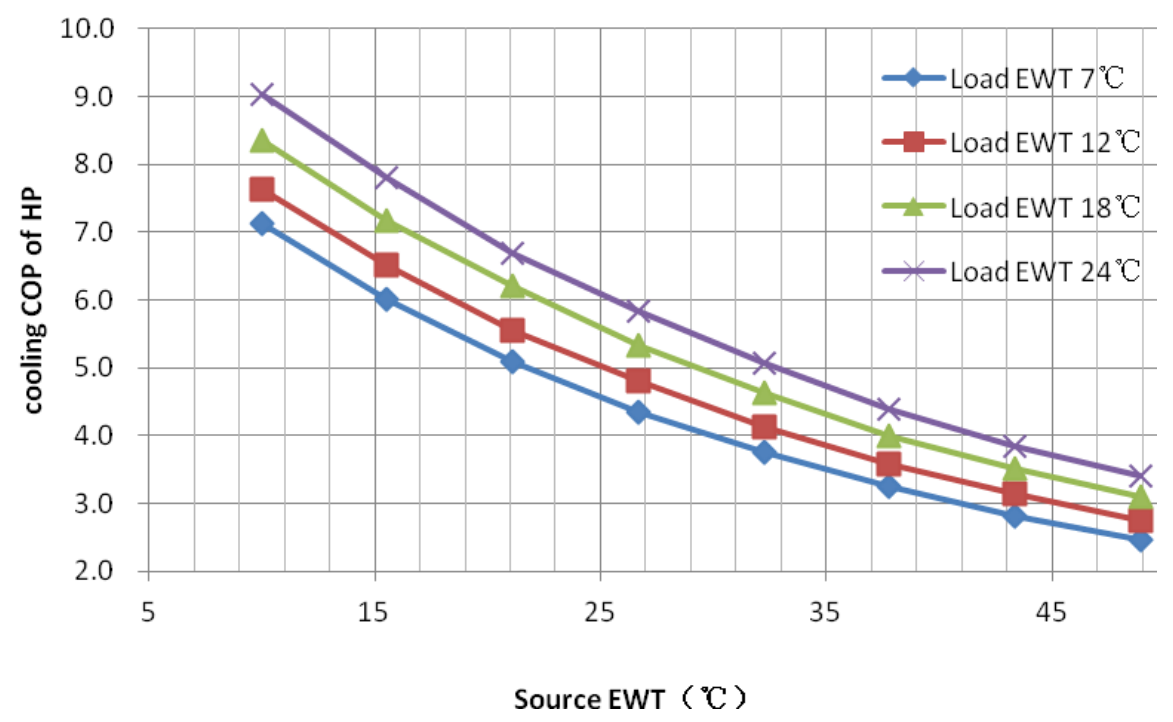

Fig.4. Characteristic performance curve describing cooling COP of heat pump

\section{Research of Thermal Balance in Compound System}

It is acquired through simulation analysis that, when the soil temperature is increased by $1{ }^{\circ} \mathrm{C}$, the cooling COP of heat pump shall drop by 3.3\%; when the soil temperature is increased by $2^{\circ} \mathrm{C}$, the cooling COP of heat pump shall decline by $5.2 \%$; when the soil temperature is increased by $3{ }^{\circ} \mathrm{C}$, the 
cooling COP of heat pump shall decline by 6.9\%. Additionally, within the acceptable scope, it is acceptable that the temperature rising raised by the 10 -year operation of the system shall not exceed $3^{\circ} \mathrm{C}$.

Thermal balance effect analysis of various operation strategy under design scheme 1.It is acquired through simulation analysis that the thermal balance effect shall be overall unsatisfactory through individually adopting six basic strategies under design scheme 1 . Accordingly, the thermal balance effect is relatively better through adopting strategy 1, 3, 5 and 6 . Under the reasonable design parameter, the soil temperature can be risen by $3.5^{\circ} \mathrm{C} \sim 4^{\circ} \mathrm{C}$ as the system is operated for 10 years. In the meantime, the total operation energy consumption of equipment in 10 years reaches between 930 940MWh through adopting the strategy 1, 3 and 6. The total energy consumption through adopting strategy 5 is relatively higher as the energy consumption of buried pipe circulating pump is increased during the transitional season, reaching $1020 \sim 1060 \mathrm{MWh}$. The thermal balance effect through adopting strategy 2 and 4 is relatively worse. The soil temperature shall be basically increased by $5{ }^{\circ} \mathrm{C}$ during the 10 -year operation. Additionally, the increased soil temperature through adopting strategy 4 reaches the highest among temperature data through adopting other strategies.

As under the design scheme 1, the requirements of thermal balance and the low energy consumption are not reached through adopting six strategies, the combined operation strategy is to be adopted. Under various combined operation strategies, the soil temperature variation and the system operation energy consumption are displayed in Table 1.

Table 1 Comparison among various operation effects of various combined strategies under design

scheme 1

\begin{tabular}{|c|c|c|c|c|c|c|c|c|}
\hline \multirow[b]{2}{*}{ Design scheme 1} & \multirow[b]{2}{*}{ Set value } & \multirow{2}{*}{$\begin{array}{c}\text { Increased } \\
\text { temperature of } \\
\text { buried pipe } \\
\text { area in } 10 \\
\text { years of } \\
\text { operation }\end{array}$} & \multicolumn{6}{|c|}{$\begin{array}{l}\text { Various total energy consumptions of equipment in } 10 \text { years' } \\
\text { operation/ (MWh) }\end{array}$} \\
\hline & & & $\begin{array}{l}\text { Heat } \\
\text { pump } \\
\text { unit }\end{array}$ & \begin{tabular}{|l} 
Buried \\
pipe \\
circulatin \\
g pump
\end{tabular} & $\begin{array}{l}\text { Load side } \\
\text { circulating } \\
\text { pump }\end{array}$ & $\begin{array}{l}\text { Cooling } \\
\text { tower } \\
\text { circulatin } \\
\text { g pump }\end{array}$ & $\begin{array}{l}\text { Cooling } \\
\text { tower }\end{array}$ & Total \\
\hline \multirow{2}{*}{$\begin{array}{c}\text { Strategy } 1 \text { and } 3 \\
\text { (temperature+ temperature } \\
\text { difference, wet bulb ) }\end{array}$} & $30^{\circ} \mathrm{C} / 2^{\circ} \mathrm{C}$ & 3.65 & 630.1 & 229.3 & 42.8 & 21.4 & 11.4 & 934.9 \\
\hline & $30^{\circ} \mathrm{C} / 3^{\circ} \mathrm{C}$ & 3.82 & 632.5 & 229.3 & 42.8 & 18.2 & 10.0 & 932.8 \\
\hline \multirow{2}{*}{$\begin{array}{c}\text { Strategy } 1 \text { and } 5 \\
\text { (temperature }+ \text { transitional } \\
\text { season open) } \\
\end{array}$} & $22^{\circ} \mathrm{C}+20 \mathrm{~h}$ & 1.54 & 621.1 & 326.3 & 42.8 & 50.7 & 25.3 & 1066.2 \\
\hline & $28^{\circ} \mathrm{C}+20 \mathrm{~h}$ & 2.38 & 632.8 & 326.3 & 42.8 & 33.2 & 16.6 & 1051.7 \\
\hline \multirow{2}{*}{$\begin{array}{c}\text { Strategy } 3 \text { and } 5 \\
\text { Temperature (wet bulb)+ } \\
\text { transitional season open }\end{array}$} & $3^{\circ} \mathrm{C}+20 \mathrm{~h}$ & 1.92 & 627.5 & 326.3 & 42.8 & 39.0 & 19.5 & 1055.2 \\
\hline & $4^{\circ} \mathrm{C}+20 \mathrm{~h}$ & 2.16 & 630.9 & 326.3 & 42.8 & 35.2 & 17.6 & 1052.9 \\
\hline $\begin{array}{c}\text { Strategy } 5 \text { and } 6 \\
\text { (transitional season open+ } \\
\text { timed open) }\end{array}$ & $\begin{array}{l}09: 00 \sim \\
18: 00+20 h\end{array}$ & 1.58 & 622.0 & 326.3 & 42.8 & 51.4 & 25.7 & 1068.2 \\
\hline
\end{tabular}

In view of this table, the temperature control, temperature difference control (wet bulb), timed open and transitional season open are respectively combined to be applied. With the exception of the data under first combined strategy of temperature + temperature control, the increased soil temperatures in 10 years under the other strategies are overall within the acceptable scope. However, operation in transitional season increases the energy consumption of buried pipe, cooling tower and cooling tower circulating pump. The total energy consumption shall be significantly larger.

Based on the mentioned comparison analysis, it is acquired that, for the new construction, to realize the thermal balance of soil through adopting the design scheme 1 shall be larger. Compared with the new construction, the design scheme 1 shall be more appropriate for the renovation of existing ground-coupled heat pump system.

As for the existing and single ground-coupled heat pump system, the soil temperature shall be elevated certainly after the certain period of heat pump's operation. Take the single ground-coupled heat pump system of this model as the example. The soil temperature increases to $24.2^{\circ} \mathrm{C}$ by $5.13^{\circ} \mathrm{C}$ after 5-year operation. If in the 5th year, the cooling tower is added to this system as to supplement the heat dissipation, the combined control of strategy 1 and 5 is adopted, the temperature set value 
reaches $22^{\circ} \mathrm{C}$, the cooling tower shall be opened for 20h during the transitional season, and the system shall continue to operation for 5 years, the soil temperature of the buried pipe area shall reach $22.53^{\circ} \mathrm{C}$. The soil temperature compared with that of 5 th year is eventually decreased by $1.67^{\circ} \mathrm{C}$. This temperature surmounts $3.46^{\circ} \mathrm{C}$ over the initial temperature. If this system continues to be operation, the soil temperature shall further decreased. Eventually, it shall decrease to the acceptable scope. The hourly heat acquisition and release of buried pipe and the cooling tower from 5th and 10th are displayed in Figure 5. The average temperature and the heat pump inflow temperature of soil in buried pipe area are displayed in Figure 6.

For some systems failing to be further used as the soil temperature is seriously increased due to the long-term operation, the cooling tower can be adopted. The cooling tower shall be connected to the buried pipe in series to cool the soil. Take this system as the example. The soil temperature shall rise to $26.32^{\circ} \mathrm{C}$ after 10 -year operation of ground-coupled heat pump system. By this time, the outflow temperature of the buried pipe is higher, and the heat pump efficiency is seriously decreased. The heat pump operation is stopped. The cooling tower shall be opened during the transitional season between Mar. 31st and May 15th and between Oct. 7th and Nov. 18th. The tower shall be opened for $10 \mathrm{~h}$ per day. One year later, the soil temperature shall drop to $24^{\circ} \mathrm{C}$. Compared with the initial soil temperature, the temperature is increased by $4.93^{\circ} \mathrm{C}$. If the operation time of cooling tower is increased, and the cooling tower is opened during the transitional season between Mar. 31st and May 15th and between Oct. 7th and Dec. 31st, and it is be operated for 20h per day, the soil temperature shall be reduced to $22.63^{\circ} \mathrm{C}$. It is increased by $3.56{ }^{\circ} \mathrm{C}$ compared with the initial temperature of the soil. In the following year, the cooling tower shall be operated to supplement the ground-coupled heat pump system. The recommended combined operation strategy can be adopted as to guarantee the constant and steady operation of compound system.

Hence, it is acquired that, the year-by-year increasing soil temperature can be resolved through adopting three combined operations strategies. However, the open scheme of cooling tower during the transitional season also increases the operation energy consumption of the system.

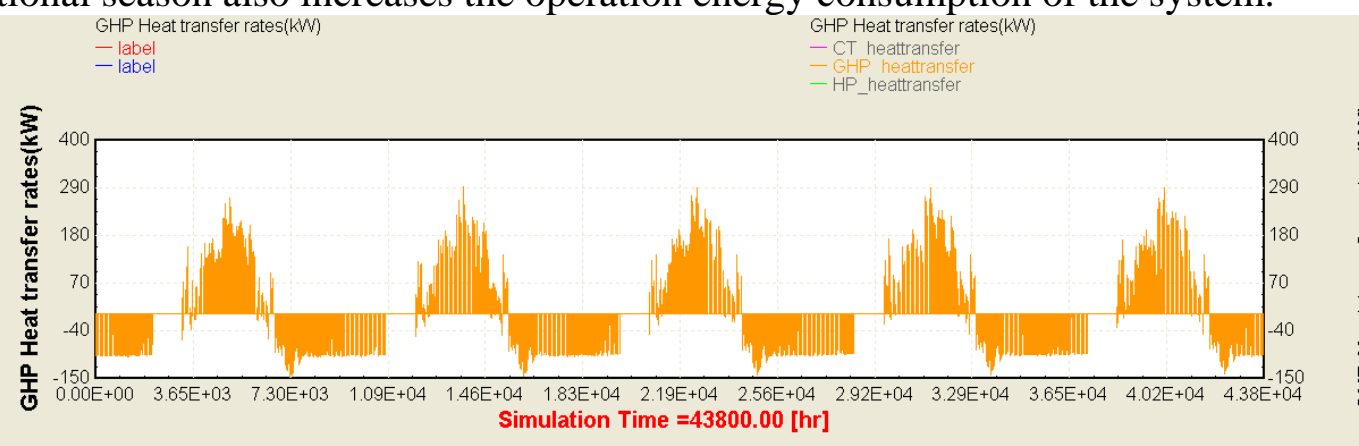

Fig.5. Hourly acquired and released heat amount of buried pipe and cooling tower (strategy 1 and 5, 5th to 10th years) 


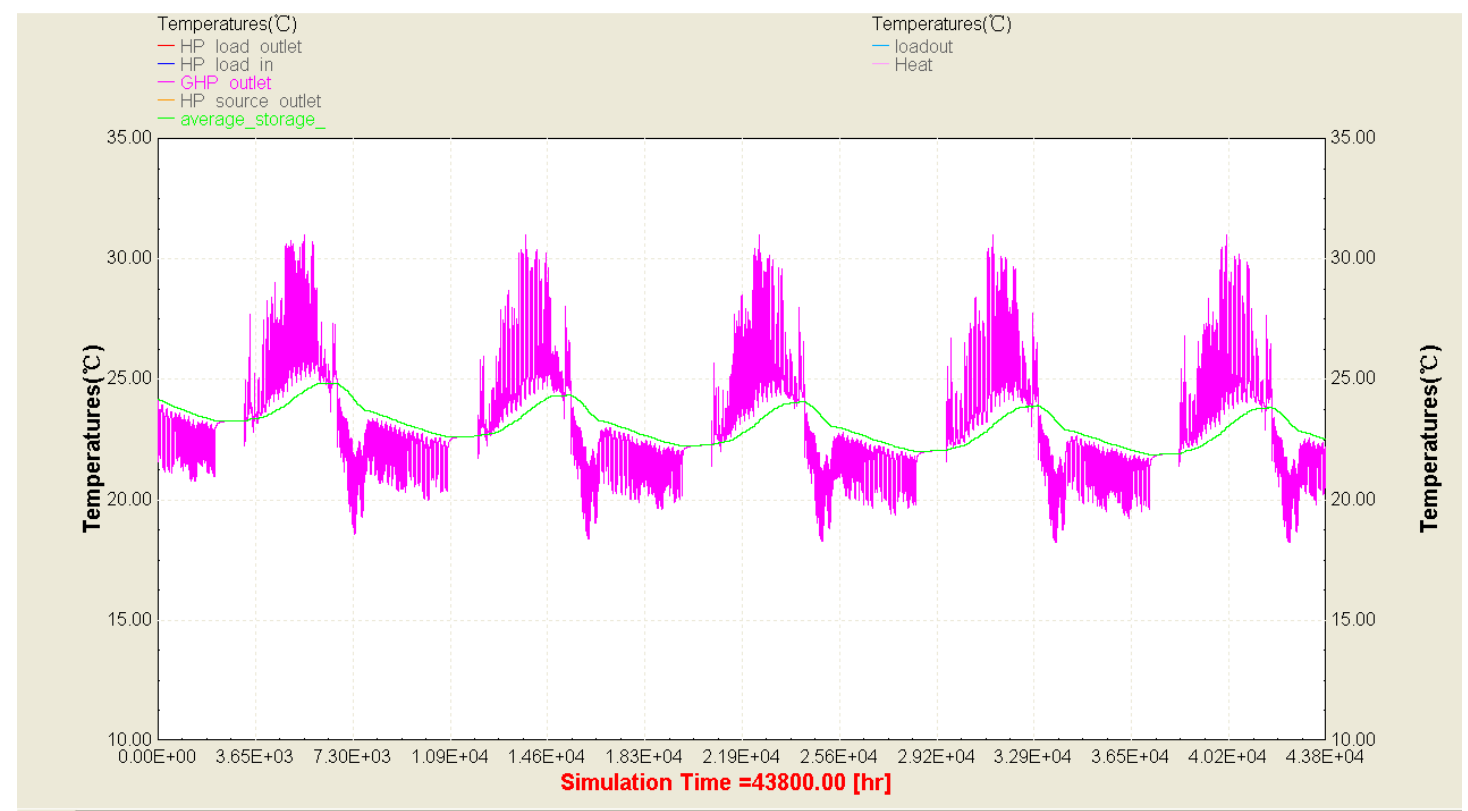

Fig.6. Soil average temperature and inflow temperature of buried pipe

(strategy 1 and 5 , 5th to 10th years)

\section{Conclusion}

As for the existing and single ground-coupled heat pump system, especially for the projects having increased the soil temperature due to the long-term operation, the design scheme 1 of cooling tower capacity shall be adopted in accordance with the thermal balance requirement. The single strategy shall be adopted, and the thermal balance requirement is not required to be reached. The combined operation with multiple strategies shall be adopted, including the combined operation of temperature control and the transitional season open, and of the temperature control and the transitional open. Under the design scheme 2, the heat pump unit shall be selected in accordance with the cooling load. The buried pipe exchanger shall be designed in accordance with the maximum heat absorption capacity. The cooling tower shall be selected in accordance with the difference between the cooling and heating load requirements. Additionally, the cooling tower shall be connected to the buried pipe via the plate heat exchanger. Under such circumstance, the thermal balance requirement can be met through adopting the single temperature control, temperature difference control (wet bulb), temperature + temperature difference (web bulb), temperature + transitional season open, and timed open strategies. Accordingly the total energy consumption during operation shall be relatively smaller through adopting the single temperature difference control or the operation of temperature control. The energy consumption shall be minimized when the temperature is set as $26^{\circ} \mathrm{C}$.

\section{References}

[1] Weisen Pan, Shizhan Chen, Zhiyong Feng. Automatic Clustering of Social Tag using Community Detection. Applied Mathematics \& Information Sciences, 2013, 7(2): 675-681.

[2] Yingyue Zhang, Jennifer W. Chan, Alysha Moretti, and Kathryn E. Uhrich, Designing Polymers with Sugar-based Advantages for Bioactive Delivery Applications, Journal of Controlled Release, 2015, 219, 355-368.

[3] Yingyue Zhang, Qi Li, William J. Welsh, Prabhas V. Moghe, and Kathryn E. Uhrich, Micellar and Structural Stability of Nanoscale Amphiphilic Polymers: Implications for Anti-atherosclerotic Bioactivity, Biomaterials, 2016, 84, 230-240.

[4] Jennifer W. Chan, Yingyue Zhang, and Kathryn E. Uhrich, Amphiphilic Macromolecule 
Self-Assembled Monolayers Suppress Smooth Muscle Cell Proliferation, Bioconjugate Chemistry, 2015, 26(7), 1359-1369. 